\title{
Post Colonial Theory and African Drama: A Critical perspective on Ananse in the Land of Idiots
}

\author{
Evans Asante ${ }^{1}$, Stephen Oppong Yaw ${ }^{2}$ \\ ${ }^{1,2}$ University of Education, Winneba, Ghana
}

*Corresponding Author: Evans Asante, University of Education, Winneba, Ghana

\begin{abstract}
This paper is a textual analysis and interpretation of Yaw Asare's Ananse in the Land of Idiots in the light of Post-Colonial Theory. The paper outlines the various aspects of post-colonial and post Afrocentric theories as used by the playwright in his work. It gives a critical perspective on the various characters, themes and other issues raised by the playwright as symbolic representations of various sectors and institutions in Africa. The paper concludes that Yaw Asare's play is a literary attempt at waging a war on European and Western imperialists who continually make life uncomfortable for the minorities, colonized and the marginalized.
\end{abstract}

Keywords: Post-Colonial Theory, critical perspective, orientalism, colonialism, Ananse Stories.

\section{INTRODUCTION}

Founded on Edward Said's Orientalism published in 1978, the postcolonial theory has spread like a wild fire, entering into fields such as literature, culture, anthropology, theatre and performance, gender, race, ethnicity, nationalism, feminism, sociology, economics, politics, history, education, language, postmodernism, among others. (Ukaegbu, 2018, Al-Saidi, 2014 \& Wang, 2018). Said in his Orientalism criticised the 'Occident'-Europe and the Western world of their intentionally orchestrated and subjective representation of the 'Orient' - Other (East/Asia) as uncivilised or uncouth so as to better their position for hegemonic and neo-colonial imperialistic opportunities. To Said, the occidental misrepresentations of the Orient are constructed through 'contrasting image, idea, personality, experience' of the Orient with 'very large mass of writers, among whom are poets, novelists, philosophers, political theorists, economists, and imperial administrators' championing the course (Said, 1978, p.2).

As a spring that would propel intensive theoretical discourse and performativity among scholars and artists, the term postcolonial which first appeared in the writings of Bill Ashcroft, Gareth Griffiths and Helen Tiffinin the1980s and has become a major theory that deals with the body of literature that originate from formerly colonised, colonised and third world nations that try to unveil, correct and push back the occidental misrepresentations of the identities of such nations (Al-Saidi, 2014). This characteristic of the postcolonial theory is shared by Barry (2006) which reveals that the postcolonial theory attempts to reverse occidental constructions of the other by attempting to replace such demeaning constructs with the authentic versions of the marginalised non-European and Western people. This is firmly agreed by Homi Bhabha who has established himself as one of the staunch scholars of postcolonial theory. Bhabha (1994, p. 171) argues:

Postcolonial perspectives emerge from the colonial testimony of Third World countries and the discourses of "minorities" within the geopolitical divisions of East and West, North and South. They intervene in those ideological discourses of modernity that attempt to give a hegemonic "normality" to the uneven development and the differential, often disadvantaged, histories of nations, race, communities, peoples. 
From the above, the postcolonial theory is a war by the formerly colonised, minorities and the marginalised people on earth who are uncomfortable with the European and Western prejudiced, subjective, and derogatory representations of their identities and histories. As the army on the battle field, against the robust and tactically disciplined Eurocentric and Western neo-colonial imperialism strategic weaponry, the believers of the postcolonial theory steadily focus on how they can win back their defamed identities and hold their place in the world. It is worth mentioning that the roles of postcolonial theorists such as Gayatri C. Spivak, Chinua Achebe, Wole Soyinka, Frantz Fanon, Aime Cesaire, and Michel Foucault among others (Ukaegbu, 2018) in the battle for 'progressive identity', 'difference and diversity' and 'quest for the past' (Belaid, 2018, p. 13, 16 \& 19) cannot be underestimated.

As one of the earliest postcolonial theorists, Spivak by her writings has defended the frontiers of the third world against the European and Western ideological domination over the years. Particularly in her Can the Subaltern Speak(1988) Spivak questions the European and Western criticism of the sati widowhood rite which in the eyes of the West is a murderous act perpetrated against Indian Hindu women by their men. She argues that while she does not support or advocate for the killing of widows, she believes that the European description of the sati rites as barbaric is only a way to strengthen the reasons for their messianic ideologies for which reason their control of India was indispensable. Spivak; whose writings project her as a staunch feminist argued that the sati rites was based on the ideology of 'reward' for the women who went through and it paralleled the western ideology that their imperialism in India was a 'social mission'. Therefore to Spivak, the Europeans had no moral justification to condemn the Hindu right which the women went through without complaints as the victims saw the practice as self-scarification and edification.

Critical to this view is how Spivak defends the sati rites even when it claims lives of poor women through indoctrination. Would Spivak hold same believe about the sati if it were a European or Western concept which had been adopted by the local Indian population? This is typical of the postcolonial theory which seems to reject any tendencies of European and Western power play over the third world. By this position, the postcolonial theory seems to care less about the internal forces that threaten the wellbeing of the third world as the attention of the theorists is fixated on identifying and dealing with the external forces-European and Western imperialism. By so doing, the army (postcolonial theorists) stand armed at the borders of scholarship and practice, ready and focused to correct the misrepresentations of the other and the third world by European and Western forces, defend the third world ideologies and by so doing push the attackers from the battle line into their own side. It appears that while this battle continues unabated, there are certain internal forces that eat dangerously into the very core of the people which impede their welfare. There could be two reasons for this in relation to the postcolonial theorists; either they do not care about the internal issues or they believe there should be other internal forces that should deal with those.

While most postcolonial discourses tread the path as discussed above, African literature seem to provide a reverse critical perspective to the postcolonial theory. While on the one part most African literature function against the hegemony of Europe and the West, they in part deal with the internal issues that that stagnate development and cause the foreign powers to spread their messianic with hidden neocolonial ideologies that the postcolonial theory wars against. In view of this while Wetmore (2001) sees African postcolonial adaptations of Greek tragedies and mythology as a political tool against Eurocentric advancement and encroachment, he also identifies that the same works of adapted literature and performances at the same time deal with internally generated issues affecting the African people. Wetmore terms this second function of African adaptations as 'post-Afrocentric'. (p.37).

Critical consideration of this concept of post-Afrocentric seems to be more grounded and versatile in African literature and performances than in just the African adaptations of Greek tragedy as Wetmore identifies. A critical example is found in the novel: No Longer at Ease by Chenua Achebe. In this novel, Achebe criticizes the western influences on Obi and Nigeria in general after he returns from Britain; but at the same time, he criticizes some aspects of the African culture which push people in public offices into acts of corruption that make the Europe and the West look down upon the African people (Achebe, 2010). 
In this paper, using textual analysis, we explore Yaw Asare's Ananse in the Land of Idiots through the lenses of postcolonial theory and Wetmore's post-Afrocentric concept. The paper, focuses on how Asare criticizes Europe and the West for their cunning machinations against Africa. It also focuses on how Yaw Asare criticizes African leaders and citizenry for the present canker of corruption by which Europe and the West find it easy to swindle Africans and get away with much wealth from the continent. The study therefore reveals that Yaw Asare's Ananse in the Land of Idiots can be view from the lenses of the postcolonial theory and the post-Afrocentric concept of Kevin Wetmore Jr.

\section{ANANSEgoro AND YAW ASARE'S ANANSE IN THE LAND OF IDIOTS}

One of the most popular characters in African and African diaspora folklores is Ananse (Spider). Ananse is described as a trickster, an imposter who is cunning in all his ways, sometimes considered as man, other times as a god. In much the same ways, sometimes Ananse is seen as a good character who tries to help society by the application of his trickery and cunningness, but mostly, he is known for duping those he comes into contact with and getting away; jumping into his web of lies, mistrust, and deceit with the fortunes he makes. Anansesem are stories primarily stories about Ananse among the Akan people of Ghana. However, because of the significance of Ananse in the folk stories, the term goes beyond the stories about Ananse to encapsulate folk stories in general among the Akans (Arko-Achemfour, 2013 \& Ngulube, 2017).

In Ghanaian theatre, Yaw Asare's Ananse in the Land of Idiots is categorized under the Anansegoro tradition. According to Asante and Edu (2018), Anansegoro is a Ghanaian postcolonial formal drama/theatre tradition which was born out of the Ananse storytelling tradition of Ghana. Music, dance, mime are some common elements that characterize the Anansegoro tradition. Peculiar about Anansegoro is the presence of Ananse as a stock character and protagonist who through dubious, cunning, trickery and other unscrupulous means succeeds in his courses. Anansegoro is Efua T. Sutherland's brainchild which has become a firmly established Ghanaian drama/theatre tradition (Asante \& Edu 2018, Appiah-Adjei, 2015, \& Olaniyan, 2015).

\section{SYNOPSIS OF THE PLAY}

Ananse, an imposter and a wanderer is arrested for committing a sacrilegious act by defiling a ritual meal meant to appease spirits of evil destinies in the kingdom of Dim-nyim-lira. As the judgment of the gods delivered by Priestess of Kompi, the sentence for Ananse's inconsiderate action is his death as a sacrifice to appease the offended spirits. However, out of greed and corruption of the King, Elder, Akpala and Odudu in what Ananse offers in exchange of his life which alone could pacify the gods, Ananse is able to deceive the entire kingdom for his life by giving the elders trips of colourful cloths he had in his possession and drops of bee honey he pours into the palms of some of the citizens of the wealthy kingdom. With the promise of showing Akpala the secret of honey making and half of the wealth he will gain by marrying with the princess. Akpala kills Pootagyiri; the princess' groom, and assists Ananse to impersonate Pootagyire in order to marry Princess Sodziisa. While Ananse greatly succeeds with his trickery, he fails to give any share of his ill-gotten wealth to Akpala and even tricks the king to kill the poor greedy aide to Ananse.

As Ananse leaves Dim-nyim-lira for the Island of Boyile which had been reserved for Sodziisa and her husband, he lives a wrecked kingdom which does not have the capacity to pursue and overtake him because, he leaves with all the three boats the kingdom owned which were built within a decade. It is for no reason but a critical fact that Yaw Asare was right to call the Kingdom of Dim-nyim-lira as the Land of Idiots.

\section{SetTing}

Although the playwright conceals the setting of his masterpiece by giving an unknown name in African history to the kingdom he writes about, there could be no doubt about the fact that the drama is set in Africa. This is because the use of mashed yam and eggs in the puberty ritual in the first scene of the play is associated with puberty ritual among some African communities (Anquandah, 2006). Again, raffia skirt and flywhisk which Priestess of Kompi uses are associated with the Priests/Priestesses of the Akuapim and in general, Akan people of Ghana (Larbi, 2002). This makes it clear that, the play is set in Ghana, a West African country of great mineral wealth, history of TransAtlantic slave trade, and British colonization. 
Another interesting material culture which reveals that the play is set in Ghana and for that matter Africa is the use of smock by King Dosey in his attempt to pursuing Ananse after it becomes clear that the kingdom has been duped. The wearing of war smock which is associated with the people of northern Ghana (Acquah, Amissah E. and Yankson, 2017). Furthermore, the presence of Ananse in the play reveals that the story is set in Ghana or associates with Ghana in one way or the other. Ananse, the hero is a stock character which Sutherland adapted from the Akan story telling session (Anansesem) in Ghana into her Anansegoro drama tradition in Ghana (Asante and Edu, 2018). Yaw Asare proves here that he was an ardent follower of the Anansegoro drama/theatre tradition.

\section{Yaw Asare and the Postcolonial Perspective}

In his Ananse in the Land of Idiots, Yaw Asare criticizes Europe and the West through his development and representation of his protagonist, Ananse. Ananse is a wanderer from a faraway land who walked through the land of Dim-nyim-lira many years ago. He defiles the ritual feast of the gods and is declared an evil soul. He is sentenced to death, but he gives a bribe of coloured woven head bands to the leaders of the kingdom in order to live. Later, abetted by Akpala, he gets Pootagyiri killed who was to marry the princess, impersonates Pootagyiri and marries Princess Sodziisa, attains the Island of Boyile, the gold, Cattle and barns of food as well as many servants who accompany them to their reserved place of abode. He finally orchestrates the killing of Akpala so that he may not have to share the gains with him as he had been promised earlier.

Yaw Asare uses Ananse as a symbol of Europe and the West who still try to find their ways back to the Africa after the slave trade and colonization of the African people with the mindset to deceive and rob the continent of its wealth through their infiltration of the cultures of Africa and the misrepresentation of the histories of the continent. As indicated above, as soon as Ananse got to Dimnyim-lira, he attacked the culture of the people- the puberty right which is in hope of sustenance of the kingdom since fertility and child birth which are associated with this traditional culture. By this desecration of the puberty ritual, Ananse threatened the sustenance of the kingdom. By this representation, Yaw Asase criticizes Europe and the West for their attacks on the African ways of life by their through their rejection of diversity and the push for universality which the postcolonial theorists fight against.

Again, Ananse in his attempt to free himself from the grip of the laws of the people and the punishment for eating the boiled eggs and mashed yam in oil; a feast for the gods, Ananse misrepresents the history of the people of Dim-nyim-lira. He misleads the Elder to believe that he is not an enemy but a friend who passed through the land many years. It is through this that he is able to exhibit the beautiful things he can offer them; the clothing offers the king and his elders to buy back his life. Asare through this act of Ananse's misrepresentation of the history of Dim-nyim-lira criticizes Europe and the West for their intentional misrepresentation of African histories to their favour, to win the heart of the people and to advance their exploitation schemes which is one great danger that the postcolonial theory wars against.

Sadly, Ananse gets away with his great success through his trickery. He gets away with huge sums of gold, cattle, servants even a wife, Princess Sodziiza of Dim-nyim-lira. By this, Yaw Asare bemoans the successes of Europe and the West against the susceptible Africa which is guarded by weak and corrupt leaders and unconcerned citizens. Asare bemoans how Africa loses great human, material and other resources to be carried away over the seas to develop Europe and the West. He bemoans how the African land is devastated by the amount of wealth that it loses to Europe and the West through their mechanization by which they lure African governments and peoples to submit to their ways, making them richer and richer, and the African people poorer and poorer.

\section{YaW Asare And the Post-Afrocentric Perspective}

Yaw Asare in his Ananse in the Land of Idiots criticizes the African people for their misconduct which brings about the success of Western and European hegemonic and neocolonial imperialism through the portrayal of the characters in his play under discussion. He makes the characters as symbols, classifying them to represent the arms of a democratic government: the executive, legislature and judiciary and the general citizenry. For instance, according to the 1992 Constitution of Ghana, there are three arms of government: Executive which includes the presidency, ministers of state, civil servants, security personnel among others, Legislature (parliament) and Judiciary (courts and tribunals). These arms work for and with the general citizenry for their own benefits. 
Yaw Asare in his play criticizes how the three arms of African governments together with the African citizenry have failed by giving away so much of the human and material resources to Europe and the West because of their inconsiderate corrupt practices. By the corrupt practices of the people, they are led to seek worthless favours and kickbacks from Europe and the Western powers, thereby leaving the welfare and security of the people to be played with by the powers of Europe and the West who he brands as tricksters who trample the African culture, misrepresent the African history to their favour to mislead the African people in order to loot the African land. This is exactly what Ananse did to Dim-nyim-lira; the Land of Idiots.

By critical analysis of the play, King Dosey is the most criticized of all the leaders and the people of Dim-nyim-lira for the successful dupe Ananse made on the kingdom. This is because, King Dosey is the head of the political administration of his kingdom. From the beginning, he appears as a robust and an uncompromised leader. However, in the face of a bribe from Ananse, he disregards his ethics and the laws, offers to Ananse an undue advantage with which he later lays and hutches his destructive plot and puts the kingdom into peril.

By this, Yaw Asare criticizes the executive arm of government, which is headed by the president for their inconsiderate ways by which Europe and the West infiltrate and subtly usurp Africa through cunning ways to get the riches of the African land. Through Ananse's deceptive gift of colourful headbands to the king and his wife, and his promise to weave pieces of beautiful colourful cloths for the princess and his groom for their wedding, as opposed to the laws of the land, he is spared his life which only could appease the gods for his desecration of their ritual feast. This act symbolizes what is often seen in most African countries where foreign companies are given tax holidays and other incentives; an advantage their African counterparts do not largely enjoy. To Yaw Asare, the presidents and ministers; the political administrative heads and civil servants of Africa think more about how they and their family members can enjoy better lives at the expense of the masses. They therefore tread the laws of their countries by engaging in corrupt practices; this to Yaw Asare leads the masses into unwarranted suffering.

Similarly, Yaw Asare uses the character, Akpala to represent the security personnel who are also placed under the auspices of the executive arm of government. Akpala; a guard who arrests Ananse for the desecration of the ritual feast for the gods and brings him to the palace. Right in front of him, the King and Elder receive Ananse's gifts, making futile his effort to bring the imposter to be dealt with by the law. He therefore sleeps off while he is on duty to guard Ananse from escaping. He later considers it right then to also take a gift from Ananse; drops of honey in his palm so that he, Ananse can have his way to whatever plans he has at his disposal. Although, from the beginning Akpala receives some drops of honey in his palm from Ananse and abets the imposter through his course, Ananse finally swindles Akpala by ceiling his lips with hard glue and making him dumb so that poor Akpala cannot reveal the secret of Ananse's trickery and fraud against the kingdom. Ananse also tricks the king to kill Akpala when the poor guard who had fallen into the web of Ananse tried to reveal the secret as he suspected that Ananse wanted to take all he had gained from the land without giving him his share as they had agreed earlier. The playwright criticizes the security personnel of Africa such as the Police, Military and Immigration Services who are also part of the executive arm of government. He criticizes that members of these services are corrupt because of the widespread of corruption among the presidency and civil servants who reduce the hard work of services to nothing by taking bribes and making the imposters have their ways. They therefore also engage themselves in the very act for which they are created to curtail. It is sad to note that according to Osse \& Norviewu (2019), Afrobarometre found that Ghanaians perceive the Police Service as the most corrupt institution in the country in the year 2019. This is actually not the case of only Ghana but the African continent in general.

Again, Yaw Asare criticizes the Legislative Arm of Government in African countries through his character; Elder. Elder is the right hand man of the king. He appears to work together with the king to see to it that laws are made and become functional. The king seeks Elder's opinion and direction in cases which he cannot take decision alone or does not understand. Interestingly, Elder unites with the king to receives Ananse's gifts and to make the trickster have his way on the kingdom. 
Yaw Asare through the character; Elder criticizes the Legislative Arm of Government in African countries for always being in support of the decisions of the Executive Arm, specifically the presidency,and refusing to subject them to total scrutiny because they enjoy from the corrupt practices of the Executive at the peril of the people they represent.

Also, through the character; Priestess of Kompi, the one who initiates the maidens into womanhood, considered as the mouthpiece of the gods and judge of the kingdom. She pronounces judgment on Ananse. Although the King tries to draft her into their corrupt actions, she refuses to yield to that. When the king refuses to be guided by her judgment, she remains silent until Ananse had duped the kingdom and gone away. Yaw Asare portrays the African judicial system as a silent institution which stays aloof in the face of the canker of corrupt practices perpetrated by the Executives and the Legislative Arms of Government. Indeed, in the events that their judgments are not upheld by the Executive and Legislature, they remain quiet and wait to see the result of the inconsiderate actions of the powers that be.

Finally, Yaw Asare criticizes the general citizenry of Africa by refereeing to them as idiots. $\mathrm{He}$ represents them by the character, Odudu. Odudu is a common citizen of the kingdom who because of the lack of privileges is considered an idiot. He is made to be an errand boy to Ananse while he wove cloths in the forest for the princess and her groom. He under the disguise of still trying to fetch water with a perforated gourd for Ananse hides and listens to the whole plot to kill Pootagyiri so that Ananse can marry the princess and share all the wealth with Akpala.

Having tasted a drop of honey given him by Ananse, he keeps his mouth shut for Ananse to achieve his plan because he wants more honey to eat. He tells about Ananse's plot and his success only after the imposter had already left to the Island of Boyile forever with the princess and all the escorts and gifts. He criticizes the African citizens who he represents with Odudu as idiots who openly looked down upon by those in power. In order to protect their interests, the citizens also take the slightest opportunity, fair or foul to get what they may never have again. By so doing, they become quiet even when the worst is happening at the blind side of those who consider themselves as the wise.

\section{CONCLUSION}

While Yaw Asare's Ananse in the Land of Idiots is seen as his personal critical response to the European and Western neocolonial machinations against Africa, he also criticizes the leadership canker in most African countries which prepare the grounds for the Western and European powers to spread their tentacles. In this play, he criticizes Europe and the West for their cunning endeavours in Africa and also criticizes the poor, inconsiderate and unwise decisions and choices made by African governments which bring about the successes of Europe and the West in their endeavours in African countries. He opens up on how Europe and the West, represented by the character; Ananse desecrate African cultures, histories and values and yet get away with so much from African through trickery and cunning manipulations of the governments of African states. He does not only bring into perspective how African leaders were and are tricked and forced by Europe and the West who went away with many African slaves, gold and other precious items to develop the European and Western world at the expense of the African continent but also reveals the cracks in modern day African leadership and how Europe and the West still trick and force the leaders and get away with great African wealth. The analysis clearly shows the following conclusions:

That Yaw Asare's Ananse in the Land of Idiots is a true postcolonial literature. This is because, like most postcolonial literature, attack on European and Western powers for their hegemonic and neocolonial imperialism is done through veiled representations as has been seen in this study. This is what is seen in this study in which Ananse is made to represent the Europe and the Western world. It reveals Europe and the Western world as crooks and tricksters who trample the cultures of Africa and also capitalize on the great weakness of the African people; corruption through trickery to hutch their unscrupulous schemes which help them to draw so much from Africa to strengthen their economies while they leave the African economies in tatters, and the people in confusion. This work of Yaw Asare, like that of other African writers such as Wole Soyinka, Chenua Achebe, Femi Osofisan, among others criticize this issue of European and Western orchestrations and machinations to weaken the cultural fabric and economic power of the African people. 
That Yaw Asare's masterpiece in other part leans onKeven Wetmore's post-Afrocentric concept, criticizing the destructiveinternal issues among the African people that open the cracks by which the plans of Europe and the West flow to widen their tentacles and scope of influence. This is what While Yaw Asare criticizes Europe and the West, he expends brute effort to criticize the African people. He calls the African land a Land of Idiots and he spares not the leaders nor the citizens from his sharp criticism. He maintains that if leaders are careful about defending the frontiers of cultures of the African land, and focus on defending them as opposed to the infiltrations Europe and the West, then Africa can maintain a good name, have fruitful and peaceful lives and also achieve great financial freedom. However, in the end, Yaw Asare paints a seemingly bizzard picture of hopelessness and irrevocable consequences of the European and Western world on the African people. Interestingly, he provides beams of hope at the very end of the play, in that in the state of confusion after Ananse had taken the princess as wife after killing Pootaagyiri and impersonating him to marry the princess, gotten so much gold, servants and livestock, and had travelled with all his gains to Boyile Island with the intension never to return any of the three boats which the kingdom of Dim-nyim-lira owned, constructing them in a decade, we see that in the confusion of the kingdom, they prepare for war. To Yaw Asare, Africa must be conscientious and determined to fight for their rightful lost positions in Economics, culture and history among others.

Having identified how viable Ananse stories could be adapted as a great weapon in the postcolonial theory and criticism, it is recommended that: African scholars continue to study Ananse stories and develop many other ways by which these stories could be used to widen the postcolonial theory and to save Africa and the oriental worlds from European and Western hegemony and neocolonial imperialism.

\section{REFERENCES}

[1] Achebe, C. (2010). The African trilogy: Things fall apart; No longer at ease; Arrow of God. New York: Alfred A. Knop

[2] Adusei, L. A. (2009, January 25). Corruption in Africa, a cancer that won't go away. Retrieved from Modern Ghana: www.modernghana.com/news/199975/corruption-in-africa-a-cancer-that-wont-go-away. html

[3] Al-Saidi, A. A. (2014). Post-colonialism Literature the Concept of self and the other in Coetzee's Waiting for theBarbarians: An Analytical Approach. Journal of Language Teaching and Research, 95-105. doi:10.4304/jltr.5.1.95-105

[4] Anquandah, J. K. (2006, April 8). The gold smith's craft. Retrieved from National Commission on Culture: www.ghanaculture.gov.gh/mod_print.php?sectionid=523

[5] Aquaah, S., Amissah, E., R. K., \& Yankson, P. d. (2017, November 23). Dress aesthetics of smock in Northern Ghana: form, function, and context. Textile Engineering and Fashion Technology, 1(2). doi:10.15406/jteft.2017.01.00013

[6] Asante, E. \& Edu, J. (2018, January 18). From Anansesem to Anansegoro: 'Literarising' Akan folktales. International Journal of Advanced Research and Development, 3(1), 348-353.

[7] Appiah-Adjei, D. (2015). Sankofa as a Universal Theory for Dramatists. Research Gate.

[8] Arko-Achemfour, A. (2013). Teaching moral values to the youth through the Ananse stories among the Akans in Ghana. Southern African Journal for Folklore Studies, 23(1)

[9] Asare, Y. (2006).Ananse in the land of idiots. Accra: Study Ghana Foundation.

[10] Atchulo, J. (2015, June 1). Corruption, the root cause of poverty in Africa. Retrieved from Ghana Web: mobile.ghanaweb.com/GhanaHomePage/features/corruption-the-Root-Cause-of-Poverty-in-Africa-360300

[11] Becker, S. (2018, April 21). These are the 15 most corrupt countries in the world. Retrieved from Cheat Sheet: www.cheatsheet.com/culture/ranking-worlds-corrupt-countries.html/?a=viewall

[12] Belaid, A. (2018). American cultural imperialism and Chinese resistance through performance: from a Postcolonial Perspective. Constantine : University of Mentouri.

[13] Berry, P. (2006). Beginning theory. T.R. Publication Pvt. Ltd.

[14] Bhabha, H. K. (1994). The location of culture. London: Routledge.

[15] Brennan, K. (2018, January 18 ). Identifying the multiple causes of poverty in Africa. Retrieved from The Borgen Project: https://borgenproject.org/causes-of-poverty-in-africa/

[16] Ghana's Constitution of 1992 with Amendments through 1996. Retrieved from constituteproject.org. 
[17] Larbi, K.A. (2002). A Study of Change and Continuity in Fante Asafo Art. Unpublished PhD Thesis, African Studies, Accra: University of Ghana, Legon

[18] Ngulube, P. (2017). Handbook of research on social, cultural and educational considerations of indigenous knowledge in developing countries. Hershey: IGI Global.

[19] Ochonu, M. (2008, November 26). Corruption and poverty in Africa: a deconstruction. Retrieved from Pampbzuka News: www.pambazuka.orggovernce/corruption-and-poverty-africa-deconstruction

[20] Olaniyan, M. P. (2015). The Effectiveness of Satire as a Dramatic Tool for Societal Reformation: Efua Sutherland's The Marriage of Anansewa, Examined. European Journal of Research and Reflection in Arts and Humanities, 3(4).

[21] Osse. L \& Norviewu. N (2019). Ghanaians perceive increase in corruption level, give government low marks on fighting graft. Afrobarometer Dispatch No. 333.

[22] Said, E. (1978). Orientalism. London: Routledge.

[23] Spivak, G. C. (1988). Can the subaltern speak? In C. N. Grossberg (Ed.), Marxism and the Interpretation of Culture (pp. 271-313). Basingstoke: Macmillian Educaion.

[24] Transparency International . (2015, December 1). People and corruption, Africa survey 2015-global corruption barometer. Retrieved from Transparency International: www.transparency.org/whatwedo/ publication/people_and_corruption_africa_survey_2015

[25] Ukaegbu, V. (2018). Post-colonialism and performance: political, cultural and pedagogic legacies and constraints. Repertorio, 20(29), 12-34. doi:10.9771/r.v0i29.25455

[26] Wang, Y. (2018). The cultural factors in postcolonial theories and applications. Journal of Language Teaching and Research, 9(3), 650-654. doi:http://dx.doi.org/10.17507/jltr.0903.26

[27] Wetmore, K. J. (2001). The Athenian sun in the African sky: modern african adaptations of Greek tragedy. London: McFarland \& Company, Inc. Publishers.

Citation: Evans Asante. "Post Colonial Theory and African Drama: A Critical perspective on Ananse in the Land of Idiots" International Journal on Studies in English Language and Literature (IJSELL), vol 9, no.1, 2021, pp. 1-8. doi: https://doi.org/10.20431/2347-3134.0901001.

Copyright: () 2021 Authors. This is an open-access article distributed under the terms of the Creative Commons Attribution License, which permits unrestricted use, distribution, and reproduction in any medium, provided the original author and source are credited. 